\title{
超微細光回路に向けたプラズモンモード金属光導波路
}

\author{
片桐 祥雅 $*$, 中野 義昭 $* *$, 小林 郁太郎 $* * *$, 光岡 靖莘 $* * * *$ \\ 篠島 弘幸 $*$, 福田 浩*, 後藤 東一郎* \\ *日本電信電話(株) NTTマイクロシステムインテグレーション研究所 \\ （テ243-0198 神奈川県厚木市森の里若宮3-1） \\ **東京大学 先端科学技術研究センター ( ₹113-8656 東京都文京区本郷7-3-1) \\ ***東京大学工学系研究科 精密機械工学専攻 (T113-8656 東京都文京区本郷7-3-1) \\ ****セイコーインスッルメンッ(株)（†270-2222 千葉県松戸市高塚新田563）
}

\section{Plasmon-Mode Metal Waveguides for Ultra-Dense Optical Integrated Circuits}

\author{
Yoshitada KATAGIRI,* Yoshiaki NAKANO,** Ikutaro KOBAYASHI,*** Yasuyuki MITSUOKA,**** \\ Hiroyuki SHINOJIMA,* Hiroshi FUKUDA,* and Toichiro GOTO* \\ * NTT Telecommunications Energy Laboratories, Nippon Telegraph and Telephone Corporation, \\ Wakamiya 3-1, Atsugi, Kanagawa 243-0198 \\ ** Research Center for Advanced Science and Technology, University of Tokyo, \\ Hongo 7-3-1, Bunkyo-ku, Tokyo 113-8656 \\ *** Department of, Faculty of Engineering, University of Tokyo, \\ Hongo 7-3-1, Bunkyo-ku, Tokyo 113-8656 \\ **** Seiko Instruments Inc. 563, Takatsuka-Shinden, Matsudo, Chiba 270-2222
}

(Received October 29, 2002)

\begin{abstract}
Surface-plasmon polaritons (SPPs) act as extraordinary electromagnetic waves having spatially squeezed field intensity distributions, that couple with oscillation of dense conductive matter and propagate at a metal-dielectric interface. Plasmon-mode metal waveguides are the channels to support their propagation. Characterization based on Maxwell equations gives clear understanding of the plasmon mode in terms of their propagation properties, such as dispersion relations. The method is extended to the analysis of the waveguides with slab structures. Experiments performed with devices having simple metal stripes on dielectric substrates and devices having micro-strip structures to show their promising performance for future ultra-high density photonic integration. An innovative trial of light confinement in a small space, where free-space light waves can never exist, is further described.
\end{abstract}

Key Words: Surface plasmon polariton, Waveguide, Optical integrated circuit

1.はじめに

屈折率差を利用した光を閉じ込めに基づく光導波路を 基盤に, 光を操作する光集積回路の概念が提唱されて半 世紀近く経つ．以来，石英系導波路や半導体光導波路を 䏘いた合分波やスイッチング素子·等, 様々な受動・能動 素子が実現され，光導波路素子技術は目覚しく進歩し た.しかし，半導体集積回路で笑現されているメモリや 論理ゲートといった基本構成要素を光集積回路で実現す るには至っていない。これは, 光の本質的な性質に拠 る. 即ち, 相対論に基づく光速一定の定理により光を直 接凍結保存することが不可能であること, 光はボーズ粒 子として振る舞うためフェルミ粒子特有のバンド端制御 性が発現できないことが, これら基本構成要素の実現を
阻んでいるのである。

光集積回路への見通しは本質的に立っていないといっ てよいが, 光集積回路微細化の努力は精力的に進められ ている. 近年の光通信の急速な進展に伴って大規模化す る傾向にある光信号処理回路を小型化するため曲げ半径 が大きく回路寸法をいたずらに大きくしている光配線部 分だけでも微細化したいという要請は，その原動力の一 つと考えてよいであろう。

これまで進められてきた微細化の主な手法は，大別し て二つある。一つは, 高屈折率コアによる強い閉じ込め に基づく手法で, コアとクラッドの屈折率が通常の光導 波路よりも大きいことからハイデル夕導波路とも呼ばれ る. 石英系，あるいは半導体系導波路いずれについても

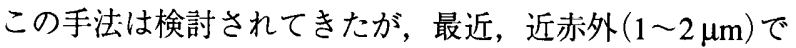


高屈折率 ( - 3.5)を示す $\mathrm{Si}$ をアとする導波路 (シリコン導 波路)が提案され，光集積回路の微細化に向けて布石され た1-6)。これらの導波路はサブミクロンのコア径と数ミク ロンの低損失曲げ半径が特徵であり，石英導波路と同等" の設計論が確立されれば大規模微小光集積回路の実現も 夢ではなくなる。もう一つの手法は，周期構造を利用し たフォトニック結晶導波路である7-11)。周期構造は波動に 対してバンドを形成する。バンドの禁止带は，フェルミ 粒子であれボーズ粒子(光)であれ排除しょうとする．2次 元または3次元的な周期構造の中に周期構造のないチャネ ルを設けると光はそのチャネルにのみ存在が許されるの

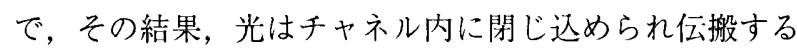
ようになる。このようなフォトニック結晶光導波路に打 いて, 強力な光閉じ込め効果は無損失直角曲げが可能で あることが理論的に指摘され，その結果は精力的な研究 の発端となった。

一・方，全く異なる第三淿手法として，金属光導波路が 提案12)されている，従来より金属反射を利用する中学尊 波路は，原理的にはミリ波導波管と同じで，炭酸ガス レーザー等の赤外光のガイドとして利用されてきた。こ こでいう金属光導波路とはこれとは原理を全く異にし， 金属中の自由電子のプラズマ振動と丽磁場との金属表面 での結合に基くものである。従って，金属導波管と区別 する意味でここではプラズモンモード金属光導波路と呼 ぶことにする。 また，この導波路を伝搬する光は，表面 プラズモンポラリトン (Surface Plasmon Polariton, SPP) 波13)とも呼ばれている.

SPP波は, 自由空間や従来の屈折率閉じ込め導波路を伝 搬する光とは異なる。物質系である電子の振動が電磁波 の電場一磁場の交番サイクル構造に組み込まれているこ と，金属誘電体界面を挟んで界面に垂直方向に指数関数 的に強度が減衰する空間的に压縮された光であること等 が主な相違点である.SPP波の研究はすでに1950年代には 行われスラブ形導波路の検討14-18) も進み, 界面近傍での SPP波の電場増大を利用し，非線形光学効果を応用した表 面分析法も提案19)された，光回路の微細化一向けた検 討20)が本格化するのは1990年代で，ファイバ形やストラ イプ形金属光導波路の理論的解析 ${ }^{21-22}$ )が行われ，種々の害 験検炋 ${ }^{23-25)}$ も報告されるようになった。

さて，プラズモンモード光導波路導入の意義を考えて みる。従来の石英系導波路の置き換えを狙うならば，単 なるバリエーションを増やすだけである，導入の真の狙 いは，回折限界を超えた微小領域で光を操作することに ある. 光は空洞の単位体積当りのモード数が波数により 規定され，限界を超えた微小空洞では光は存在できなく なる。このことは逆に空洞の寸法で光を本質的に操作で きることを意味する．通常このような微小空洞は一辺が 波長オーダーの立方体程度の大きさとなるため作製には 種々の困難性が伴う。しかし，はじめから界面に垂直な 方向の電磁場強が界面近傍に圧縮されているSPP波に対し ては, 1次元自由度が減っている分空洞の設計余裕が生ま れると期待される。このようなSPP波を利用した回折限界 以下の微小領域への光閉じ込めについていくつかの報告
がなされている，それらは，可能性を指摘するにとどま らず26)，波長超微細ホールの光伝搬実験検証 ${ }^{27) に つ い て ~}$ も報告している.

本稿では，SPP波抢よびその導波路であるプラズモン モード金属光導波路について, 理論と実験検証について 述べる。まず，金属一誘電体界面を伝搬する最も単純な SPP波をMaxwell方程式に基づき理論に記述し，その特徴 を実際の金属の誘電率を使って数值的に明らかにする. 次に, 将来の光集積回路のみならず回折限界の光操作を 検証する素材としても有望なスラブ形のプラズモンモー ド金属光導波路の理論を述べるとともに，擬似1次元金属 など究極の微細金属線路を対象とした超微細化光導波路 の可能性についても言及する。最後に，これらの理論を 検証するため，管者らがこれまで行ってきた実験を紹介 する。具体的には，ストライプ形の光導波路を対象と し, 単純片界面形導波路抢よびスラブ導波路の变形とし てのストリップ形導波路の実験結果を示す。さらに，従 来の光導波路の閉じ込め伝搬機構では説明ができない, 急峻な曲げ部分を含む導波路の伝搬実験についても紹介 し，プラズモンモード金属光導波路がいかに従来の光導 波路と異なるかを実証する.

\section{2. 理論的考察}

\section{1 プラズモンポラリトン $(\mathrm{SPP})$ 波の描像}

一般にプラズモンとは，金属中の自时電子の素励起の 一つで, 通常は進行方向に対して粗密分布を形成する縦 波である。このため，横波である電磁波とは百接結合で きない(Fig. 1(a))。しかし，対称性が破壊される界面では 電子の界面に垂直な方向の振動により表面に電子分極が 形成され，表面に沿った表面電荷の粗密波，即ち表面プ ラズモンが発生する。この波は垂直方向の電子の運動に よるのであるから横波と考えられ，TM偏波の光と結合可 能である (Fig. 1(b))。このように, 電磁場と電子の振動 が結合した状態が，プラズモンポラリトン (SPP) 波の正体 である。

プラズモンモード金属導波路を伝搬するSPP波は，光の 放射・吸収を伴わない場合，式(1)に示すMaxwell方程式 により記述できる．そこで，これを基にSPP波について理 論的に論じることにする。

$$
\left.\begin{array}{l}
r o t \mathbf{E}=-\mu \frac{\partial}{\partial t} \mathbf{H} \\
\operatorname{rot} \mathbf{H}=\varepsilon_{0} \frac{\partial}{\partial t} \mathbf{E}+\mathbf{J} \\
\operatorname{div}(\varepsilon \mathbf{E})=0 \\
\operatorname{div}(\mu \mathbf{H})=0
\end{array}\right\}
$$

まず，SPP波の特徵の一つである表面局在性について述

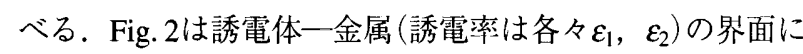
おける電磁波の場の成分を二つの固有モード(TM拉よび TEモード)に分けて図示したものである。誘電体の誘電率 は正 $\left(\varepsilon_{1}>0\right)$ であるが, 金属の誘電率は通常負 $\left(\varepsilon_{2}<0\right)$ と なる。これについては後で詳細を述べる，界面内の磁場 


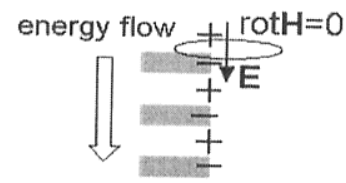

(a)

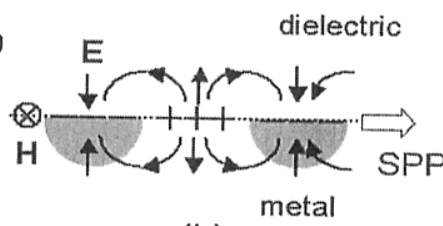

(b)
Fig. 1 Field configurations of electromagnetic waves at a surface for (a) TM and (b) TE mode.

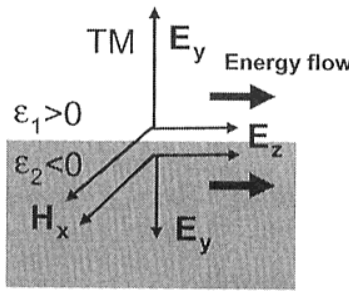

(a)

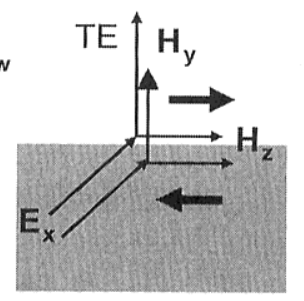

(b)
Fig. 2 Various plasma oscillations in metals. (a) Longitudinal plasma osicalltion (volume plasmon), and (b) surface plasma oscillation.

$\mathrm{H}_{\mathrm{x}}$ と垂直挹よび進行方向に沿った電場成分 $\mathrm{E}_{\mathrm{y}}, \mathrm{E}_{\mathrm{z}}$ を有す るTMモードでは(Fig. 2 (a)), z方向のポインティングベ クトルは誘電体と金属側で逆となる。しかし，金属側で はエネルギー密度は負と定義されるので，エネルギーの 伝搬方向はいずれの媒体でもz方向である。また，界面に 垂直な方向のポインティングベクトルは界面で連続とな るが，金属ではエネルギーの流れる向きが逆となるので 界面方向のエネルギーの流机は相殺される。このとき, 界面を介してエネルギーのやり取りはあってもよく、こ のやりとりが電磁場を界面に局在させるための力である と考えてもよい，一方，TEモードについて考えてみる。 TE波は, 界面内の電場Ex と垂直拈よび進行方向の磁場 $\mathrm{H}_{\mathrm{y}}, \mathrm{H}_{\mathrm{z}}$ を有する。 $\mathrm{E}_{\mathrm{x}}$ 㧍よび $\mathrm{E}_{\mathrm{z}}$ は界面で連続である。ま た，界面に垂直な磁場成分が界面を挟んで反転すること は単一磁荷が存在しないことから許されない。これらの 条件を加味すると, エネルギーの流れは誘電体と金属側 で逆となる.SPPという一つの波でこのような状況は考え 難く, むしろ界面に局在するTE波は存在しないと考える べきである。

以上の考察から，金属誘電体界面に現れるSPP波はTM 波であることがわかった，そこで，金属の誘電率が負で あることを述べる。

原子束縛性の小さい金属では，金属電子を電子間相互 作用抢よび結晶格子による散乱を無視できる自由電子ガ スとして考えることができる。このような電子の運動方 程式は, 光の交番電場を外力と考えて,

$$
m \frac{d^{2}}{d t^{2}} \mathbf{r}+m \gamma \frac{d}{d t} \mathbf{r}=-e \mathbf{E}
$$

と書ける。ここで $m$ は電子質量, $\mathbf{r}$ は電子の位置(ベクト ル), $\mathbf{E}$ は光波の電場, $\gamma$ は電気伝導度に関するパラメー夕 を表す. 角周波数 $\omega$ の光の電場 $\mathbf{E}$ は振動項 $\exp (-i \omega t)$ を含ん でいること, 実効電流密度Jを局所電子密度 $\mathrm{N}$ とその周辺
の電子の速度 $\mathrm{dr} / \mathrm{dt}$ 用いて

$$
\mathbf{J}=-e N \frac{d}{d t} \mathbf{r}
$$

であること，さらにこの電流による分極が $\mathbf{P}=i \mathbf{J} / \omega$ あ゙ある ことを考慮すると, 電子系の比誘電率 $\varepsilon_{\mathrm{m}}$ は次の上うに導 出できる。

$$
\varepsilon_{m}=1-\left(\frac{\omega_{p}}{\omega}\right)^{2} \cdot \frac{1-i / \omega \tau}{1+1 /(\omega \tau)^{2}}
$$

ここで, プラズマ振動数： $\omega_{p}=\sqrt{N e^{2} /\left(m \varepsilon_{0}\right)}$, 緩和時間： $\tau \equiv 1 / \gamma$ を用いている.

光波と自由電子ガスとの相互作用は, 比誘電率の実数 部により特徴付けられる.プラズマ振動数を境に, 高周 波数(短波長) 側では比誘電率となるのに対し，低周波数側 (長波長) 側では負となる. 従って, 光電子放出等の相互作 用を除けば，通常の誘電体と同様に電子系は高周波数領 域で光に対して透明媒体として振る舞う。一方, 比誘電 率が負となる低周波数領域では波数が虚数となるので, 通常の電磁波は存在できない。このとき，人射しょうと する光は表面で全反射する.

金属の誘電率が負となることが金属性の条件である. この金属性を強めるためには, 式(3)からプラズマ振動数 を高くすればよいことがわかる。このため電子密度が高 く有効質量 $(m)$ が小さい金属が望まれる. Fig. 3に種々の金 属材料の誘電率(実数部)の波長依存性を示す。 $\mathrm{Cr}$ 除き $\mathrm{Au}, \mathrm{Ag}, \mathrm{Ta}$ 等の貴金属系の材料28)のほか広い波長带で強 い金属性を示す $\mathrm{Al}$ が利用可能である。但し Alは表面酸化 により電導性が大幅に劣化しやすく, SPP波の伝搬を阻害 する要因となりうる。

\subsection{SPP波の諸性質}

表面局在するSPP波はTM波であることがわかったの で，次に電磁場に関する基礎方程式をMaxwell方程式 (1) から導出してみる.SPP波に対して指数関数的に減衰する 特殊解を仮定して伝搬定数を $\beta$ とすると, SPP波は次のよ うに記述できる。

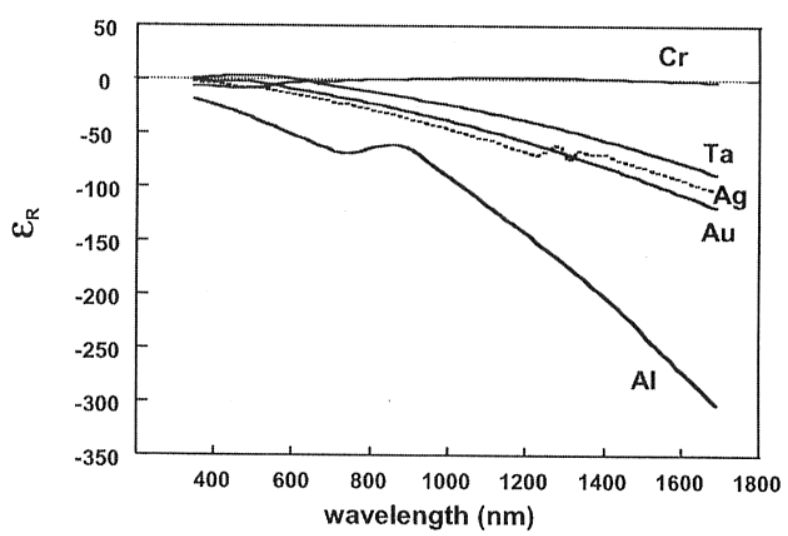

Fig. 3 Wavelength dependence of dielectric constant for various metallic materials. 


$$
\left.\begin{array}{l}
\mathbf{E}=\mathbf{E}_{0} f(y) \exp [i \beta z-\omega t] \\
\mathbf{H}=\mathbf{H}_{0} f(y) \exp [i \beta z-\omega t] \\
f(y)=\exp \left(-S_{1} y\right), y \geq 0,=\exp \left(S_{2} y\right), y \leq 0
\end{array}\right\}
$$

電磁場の各成分をMaxwell方程式に入れて連続の条件と合 わせて解くと，伝搬定数と減衰パラメー夕 $\left(\mathrm{S}_{1}, \mathrm{~S}_{2}\right)$ を次の ように定めることができる.

$$
\left.\begin{array}{l}
\beta=k_{o} \sqrt{\frac{\varepsilon_{1} \varepsilon_{m}}{\varepsilon_{1}+\varepsilon_{m}}} \\
S_{1}=\sqrt{\beta^{2}-\varepsilon_{1} k_{o}^{2}} ; S_{2}=\sqrt{\beta^{2}-\varepsilon_{m} k_{o}^{2}}
\end{array}\right\}
$$

これらの表面局在波の解からSPP波の諸性質を導出する ことができる．まず，伝搬定数 $\beta$ 実数部から分散を計算 してみる.Fig. 4(a)は，Auと真空 (または空気)界面及び $\mathrm{Au}$ と $\mathrm{SiO}_{2}$ 界面で励起されるSPP波の分散関係を誘電率の実 測値から求めたものである. 長波長領域 $(\omega \rightarrow 0)$ の領域で SPP波の分散は真空の分散に漸近する一方，短波長領域で はSPP波は減速する.SPP波の $\omega$ - $\beta$ 分散曲線は常に金属表 面に接している誘電体媒質の分散よりも右側にある。こ れは誘電体媒質の電磁場とSPP波とは直接相互作用するこ とはないことを意味する。しかし， $\mathrm{Au}$-真空界面のSPP波 の分散曲線の一部は $\mathrm{SiO}_{2}$ の分散曲線の左側にあるので，直 接エネルギーの交換が可能である. 光学的なトンネル効 果を使うとSPP波を誘電体媒質から直接励起することも可 能となる。この原理を利用したのがATR結合法である.

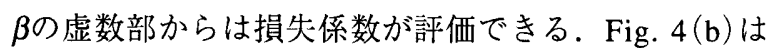
種々の材料界面におけるSPP波の伝搬損失係数を計算した もので，金属性が強い近赤外領域で低損失伝搬の可能性 が示されている. 特に $1.55 \mu \mathrm{m}$ 近傍の光ファイバ通信領域 では，酸化の影響がない $\mathrm{Au}-\mathrm{SiO}_{2}$ 界面で実用に供し得る $100 \mathrm{~cm}^{-1}$ 以下の低損失性が得られている.

さらに, 式減衰パラメータ $\mathrm{S}_{1}, \mathrm{~S}_{2}$ を定めることにより電 場・磁場の振幅分布を求めることができる．Fig.5はSPP波 特有の減衰する強度分布をAu-空気及びAu-Siについて計算 したものである。場の強度は，金属内部では数十ナノ メートル以下で急速に減衰するが, 誘電体側では緩慢に 隇衰する。この誘笔体側の場の広がりは回折限界に扝け る最小光スポット程度であるが, 強度の尖塔値は飛躍的

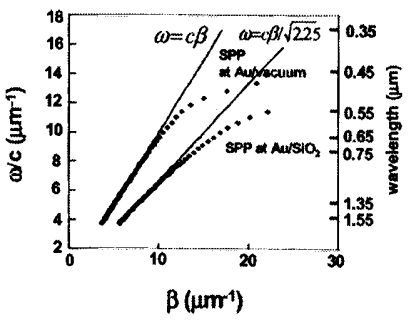

(a)

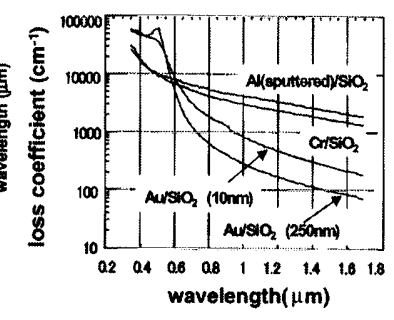

(b)
Fig. 4 (a) Dispersion relation of SPP waves at the Auvacuum interface, and (b) propagation loss coefficients as a function of wavelength for SPP waves at various interfaces using measured dielectric constants.

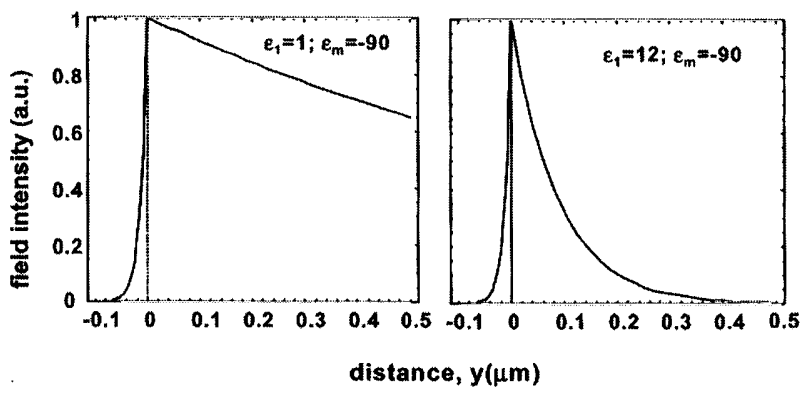

Fig. 5 Field intensity profiles of SPP waves at metal-insulator interfaces $(\lambda=1.55 \mu \mathrm{m})$ for different dielectric materials with dielectric constants of 1 and 12 .

に増大し，近赤外領域で10000に達する。

\section{3. 金属光導波路}

自由空間の光を捕捉してSPP波として金属表面に局在さ せながら界面に沿って光を伝送する光導波機構を百いに 干渉し得る複数の界面から成る系に発展させると, 従来 の誘電体導波路と同梯に，スラブ形導波路を構築するこ とができる。このような金属光導波路では，構造は3次元 で複雑さは単純界面伝搬よりも格段に增すものの設計の 自由度が上がるので, 微細な光回路を実現するための光 配線として見た場合に多くの利点がある.

$\mathrm{SPP}$ 波の導波路の最も単純なものはスラブ形導波路であ る. 導波路の形態には金属コア型とトンネル型(誘電体コ ア型)の二つがある．前者は単純な配線に適した構造で, 3次元光配線への可能性を持っている. 後者はマイクロ波 のストリップ線路に類似の構造であり, 電磁場を遮蔽し て高密度に実装する光集積回路への適用が期待できる.

\section{1 金属コア形光導波路}

Fig. 6 (a) に2次元金属板から成る金属コア形の光導波路 の構成を示す．金属内部でSPP波の電磁場の強度は急速に 減衰するが，十分厚みが小さい場合には二つの金属表面 のSPP波モードが結合する。簡単のため_.つの誘電体が同 一である場合 $\left(\varepsilon_{1}=\varepsilon_{2}\right)$ を考える。二通りの非放射の結合 モードが存在する，即ち，表寒のSPPが同位相で結合する 場合 (対称モード：symmetric mode) と180度ずれて結合す る場合(非対称モード：asymmetric mode)がある(Fig. 6 (b)). 対称モードでは電場と磁場が金属の中央の面 $(\mathrm{y}=$ $\mathrm{h} / 2$ ) で対称となり, 進行方向に沿って光周期の交番分極が 発生する。一方，非対称モードでは，進行方向と垂直に 光周期の交番分極が発生する，従って，対称モードは縦 波的，非対称モードは横波的である。いずれの場合も電 磁場分布は数学的には双曲型関数により単純化され, 非 対称モードでは

$$
\left.\begin{array}{rl}
f(y) & =\cosh \left[S_{2}(y-h / 2)\right] ; 0 \leq y \leq h \\
& =\cosh \left(S_{2} h / 2\right) \exp \left[-S_{1}(y-h)\right] ; y \geq h \\
& =\cosh \left(S_{2} h / 2\right) \exp \left(S_{1} y\right) ; y \leq 0
\end{array}\right\}
$$

となり，対称モードでは， 


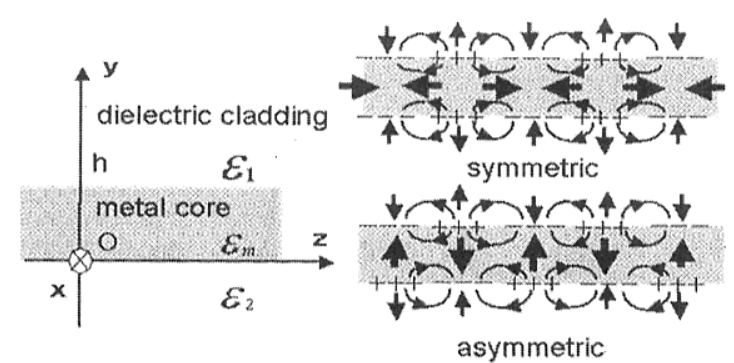

(a)

(b)

Fig. 6 SPP waveguide with metal-core geometry. (a) Basic structure and (b) field configurations for asymmetric and symmetric fundamental modes.

$$
\left.\begin{array}{rl}
f(y) & =\sinh \left[S_{2}(y-h / 2)\right] ; 0 \leq y \leq h \\
& =\sinh \left(S_{2} h / 2\right) \exp \left[-S_{1}(y-h)\right] ; y \leq h \\
& =\sinh \left(S_{2} h / 2\right) \exp \left(S_{1} y\right) ; y \leq 0
\end{array}\right\}
$$

となる。これらの式から磁場は直ちに求まる。その磁場 からMaxwell方程式に従って電場 $\left(\mathrm{E}_{z}\right)$ を導出して連続の条 件を適用して次式を得る.

$$
\left.\begin{array}{ll}
\varepsilon_{m} S_{1}+\varepsilon_{1} S_{2} \tanh \left(S_{2} h / 2\right)=0 & \text { (asymmetric mode }) \\
\varepsilon_{m} S_{1}+\varepsilon_{1} S_{2} \operatorname{coth}\left(S_{2} h / 2\right)=0 & (\text { symmetric mode })
\end{array}\right\}
$$

これらの方程式を数值解析することにより減衰パラ メータ $\mathrm{S}_{1}, \mathrm{~S}_{2}$ および伝搬定数 $\beta$ を決定することができる.

Fig. 7 (a) はAu-真空に対して伝搬定数の実数部から種々の 膜厚について分散を計算したものである。対称モードは 真空の分散にほぼ一致するが，非対称モードは短波長領 域で減速する分散特性を有していて, その減速の程度は 薄膜化とともに増大する。これは, 横波的な垂直方向の 電子の運動が制限され, 速度の遅い進行方向に沿った電 子の振動が顕著となるためと考えられる。一方, 損失に 相当する伝搬定数の虚数部の波長依存性をFig. 7 (b) に示 す. 進行方向に沿って金属内部まで浸透した電子振動が 支配的な対称モードは損失が大きいが，金属性が強くな る長波長領域で損失低減する。一方, 交番表面電流が支 配的な非対称モードの損失は対称モードと比較して3桁程 度小さくなっていて, この低損失性は波長 $0.8 \mu \mathrm{m}$ の近赤外

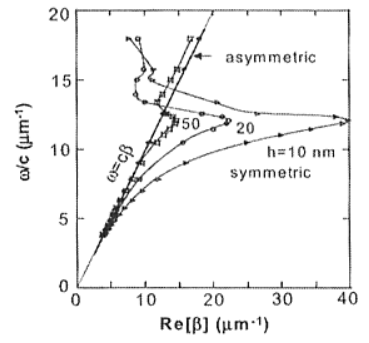

(a)

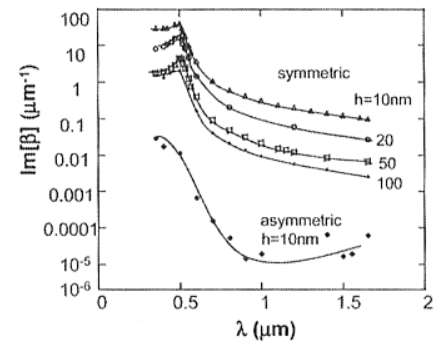

(b)
Fig. 7 (a) Dispersion relation and (b) loss coefficients as a function of wavelength for SPP waves propagating along slab waveguides with metal $(\mathrm{Au})$ cores. The variation of core thickness ranges from 10 to $100 \mathrm{~nm}$.
領域から現れる.

金属コア形光導波路の究極は単一原子層で，いくつか の物質系で実現されているとともに，金属層で形成され る2次元電子系 ${ }^{29)}$ に特有の現象が観測されている. その典 型として遷移金属カルコゲナイド $\left(\mathrm{MX}_{2}\right)$ 系の層状結晶があ げられる。このような物質では，2次元のSPP波励起が期 待できる。さらにこの概念を拡張して，1次元金属光導波 路を考えることもできる，その極限は同様に単一原子鎖 であり，いくつかの化合物が利用できる可能性がある. 例えば白金錯体 $(\mathrm{KCP})$ はd軌道の重なりにより擬1次元電子 系を形成する擬1次元金属で(Fig. 8), 1次元SPP波を励起し 得る。この他にも1次元金属として, TTF-TCNQ, ポリア セチレン, 1次元遷移金属カルコゲナイド $\left(\mathrm{MX}_{3}\right)$ 等があげ られる。これらの化合物を任意に形成し集積化できれ ば，微細加工技術によらない革新的な超高密度配線技術 が実現できることになる。

\section{2 トンネル形光導波路}

Fig. 9 (a)に2枚の半無限金属を誘電体スペーシングhで 隔てて対向させて成るトンネル形の光導波路の構成を示 す. 金属コア形光導波路と同様に金属界面の局在波が結 合して，対称・非対称の二つの独立なSPP波のモードが形 成される (Fig.9 (b))。これらのモードは双曲型関数で記 述でき, SPP波の基礎方程式

$$
\left.\begin{array}{ll}
\varepsilon_{1} S_{1}+\varepsilon_{m} S_{2} \tanh \left(S_{2} h / 2\right)=0 & \text { (asymmetric mode) } \\
\varepsilon_{1} S_{1}+\varepsilon_{m} S_{2} \operatorname{coth}\left(S_{2} h / 2\right)=0 & \text { (symmetric mode) }
\end{array}\right\}
$$

を得る. 前節と同様にこれらの方程式の数值的に解くこ とにより，スペーシングをパラメータとして伝搬定数 $\beta$ を 各モードについて決定できる，Fig. 10は，誘電体スペーシ ングに $\mathrm{SiO}_{2}$ コアと $\mathrm{Au}$ クッドから成る導波路について分 散および損失の波長依存性を対称・非対称モードについ て計算した結果である。非対称モードでは, 誘電体 ギャップhの低減とともに減速するSPP波の分散特性(Fig. $10(\mathrm{a}))$ が得られている。ギャップ低減とともに損失は増 大するが，いずれのギャップでも長波長領域で損失が大 幅に低減される (Fig. 10 (b)) . 一方, 対称モードの分散は 誘電体で満たされた自由空間の分散とさほどの違いはな い(Fig. 10 (c))。これは, SPP波が表面電子にサポートさ れて直進するためと考えられる。但し，このようなSPP波 はギャップ中で自由空間の電磁波と同様に振る舞うた め，伝搬が不可能となるカットオフ波長が出現する (Fig. $10(\mathrm{~d}))$.この波長はギャップの高々2倍程度であるため,

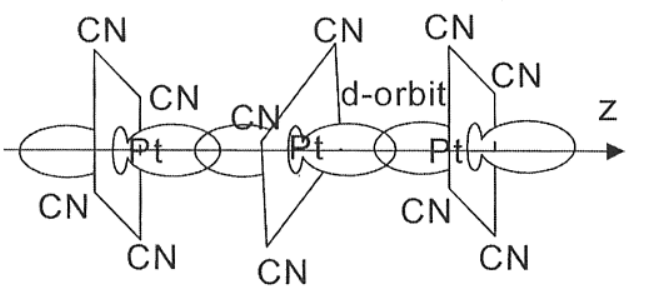

Fig. 8 One-dimensional metallic structure using KCP chains providing electron passage assisted by $\mathrm{d}$-orbit overlap. 


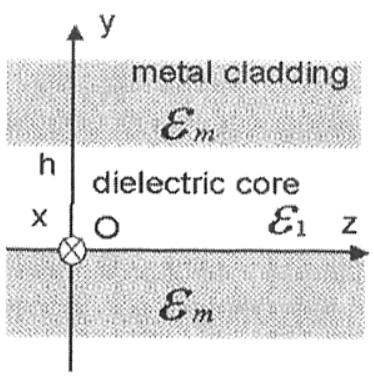

(a)

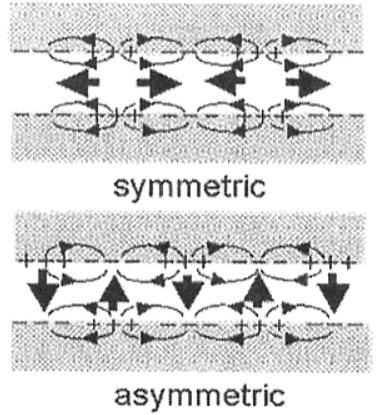

(b)
Fig. 9 SPP waveguide with dielectric core embedded by semi-infinite metals. (a) Basic structure and (b) field configurations for asymmetric and symmetric fundamental modes.

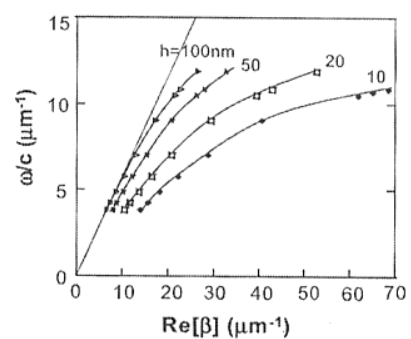

(a)

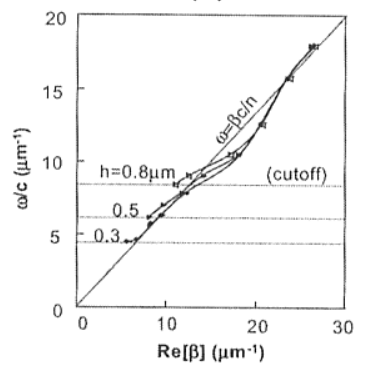

(c)

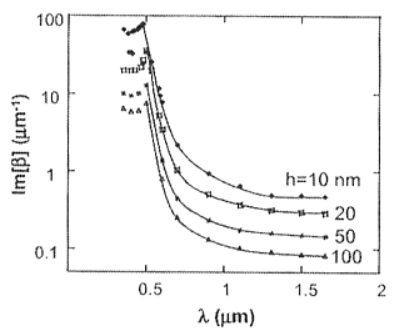

(b)

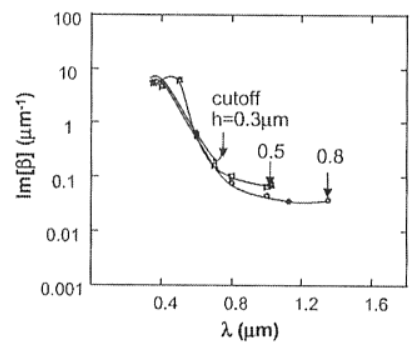

(d)
Fig. 10 Dispersion relation and corresponding loss coefficient versus wavelength curves for (a) (b) asymmetric and (c) (d) symmetric modes propagating along metal waveguides with dielectric cores consisting of $\mathrm{Au} / \mathrm{SiO}_{2} / \mathrm{Au}$ layer structures.

対称モードが回折限界を大きく超えて狭ギャップを通過 することはできない. 対称モードの損失が長波長領域で 低減するのはこれまでのSPP波のモードの傾向と同じであ る.

トンネル型金属光導波路の特徴の一つは，金属による 電磁場の強い遮蔽効果による回折限界以下の微小誘電体 コア内への電磁場閉じ込めである. Fig. 11 は厚さ $100 \mathrm{~nm}$ の $\mathrm{SiO}_{2}$ コアと $\mathrm{Au}$ クラットから成る金属光導波路の電磁場の 強度分布を波長 $1.55 \mu \mathrm{m}$ で計算した例で，誘電体媒質の波 長の10分の1の領域に電磁場が閉じ込められることを示し ている。このような微小空間への電磁場の閉じ込めは, 共振器量子電磁気学 (cavity quantum electromagnetic dynamics)の検証のみならずナノスケールで発現する量子 効果を利用した種々のデバイスへの応用が期待できる。

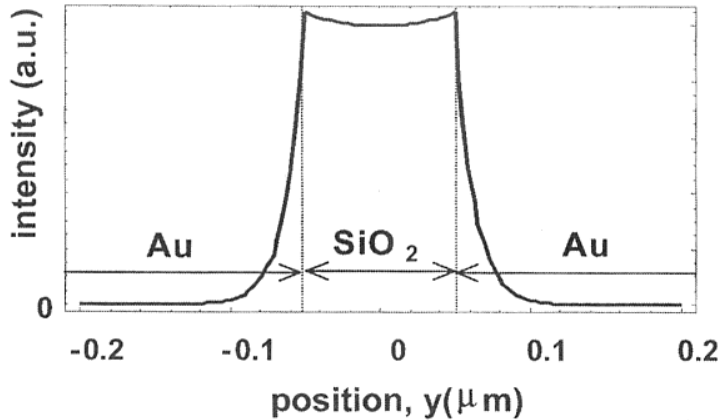

Fig. 11 Field intensity profiles of SPP waves of $\lambda=1.55$ $\mu \mathrm{m}$ for tunnel-type waveguides with dielectric core ( $h=100 \mathrm{~nm}$ ) sandwiched by metal cladding.

\section{4. 実験検証}

金属誘電体界面におけるSPP波の伝搬機構に基づく光導 波路の検討は1970年頃から始まり，2次元的スラブ形導波 路を中心に多くの論文が報告された．1990年代になって SPP波は回折限界を打破する光閉じ込めにより伝搬するこ とが指摘され，ファイバ形や平面形を問わず誘電体導波 路と同様の多様な導波路構造が提案された。しかし，光 周波数領域では誘電体導波路よりも桁違いに大きい伝搬 損失がある上に光通信の進展に伴って石英系の平面形光 導波路素子技術が目覚しく進展する中で，金属光導波路 が多大な注目を集めることはなかった。

ところが，超高密度光実装や超高密度光記録の分野で 回折限界に制限されている従来の光素子技術の限界を打 破するため, SPP波ならびに金属光導波路が着目されはじ めている. 伝搬損失が大きい可視光領域での検討も精力 的に行われており，又トライプ形状の導波路の検討が行 われているほか, 光記録用プローブヘッドへの適用も進 められている。我々は，長波長帯でSPP波の伝搬損失が著 しく低下することに着目し, 近赤外領域 $(1.5 \mu \mathrm{m}$ 波長带 $)$ で 金属光導波路の実験検証を試みてきた。同様の試みは他 からも報告されるようになり, SPP波の定量的解析が今後 進んで超微細光回路へ向けた検討が加速することが期待 される、本節では, 我々が行った検討のいくつかを紹介 する。

\section{1 片界面形金属光導波路}

最も単純な構造の導波路である片界面形の金属光導波 路に対してSPP波の伝搬実験を行った。Fig. 12 (a) は導波 路の断面構造で, 厚み $250 \mathrm{~nm}$ の金属 $(\mathrm{Au})$ ストライプが $\mathrm{SiO}_{2}$ 薄膜 $(300 \mathrm{~nm})$ を介して InP基板上に形成される. Fig. 12 (b)は，作製した金属光導波路の端面近傍の走査電子顕 微鏡 $(\mathrm{SEM})$ 像である.

この導波路では，金属と基板側誘電体との界面に沿っ たSPP波の励起を狙いとして，テーパーファイバ $(1.55 \mu \mathrm{m}$ 分散シフトファイバ)により導波路端の金属誘電体界面部 分を $1.55 \mu \mathrm{m}$ 带単一モードレーザーで照射した. Fig. 12 (c) は他端面を長波長带に感度を持つ撮像管により種々のス トライプ幅について $(5 \mu \mathrm{m}(\mathrm{i}), 30 \mu \mathrm{m}(\mathrm{ii}))$ 観測したもので ある. TM偏波照射時にのみストライプ部に集中した強い 


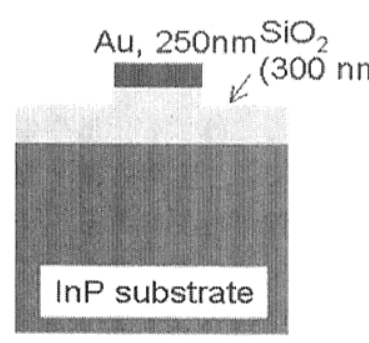

(a)

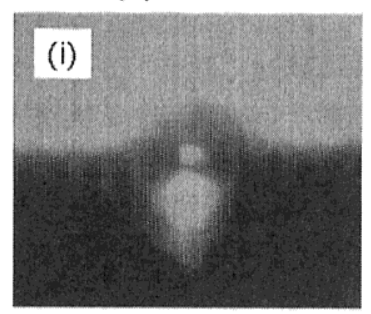

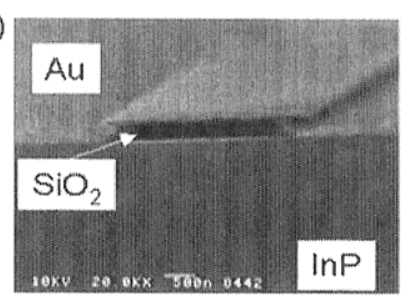

(b)

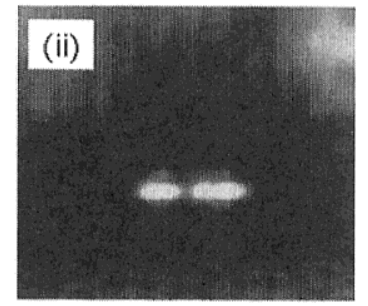

(c)

Fig. 12 Demonstration of SPP propagation along a simple metal stripe waveguide at a wavelength of $1.55 \mu \mathrm{m}$. (a) Cross-sectional view of the waveguide consisting of a 250-nm-thick Au stripe on a 300-nm-thick$\mathrm{SiO}_{2}$-film-coated InP substrate and (b) an SEM photograph. (c) Illumination images observed with an IR camera, which confirm SPP propagation along (i) $5-\mu \mathrm{m}$-wide and (ii) $30-\mu \mathrm{m}$-wide stripes. SPP excitation was performed by the end-fire method using a tapered optical fiber.

発光像が得られており,これらの像がSPP波伝搬の証拠と 考えられる。

得られた像の詳細を観察し伝搬モードを検討した。得 られた近視野像は，導波路幅が狭い場合には横単一モ一 ド，幅が広い場合には横多モードを示していた。但し， SPP波のプロファイルは金属内部で回折限界を超えている ので，この結果をもってただちに伝搬モードとすること はできない，また，SPP波はMaxwell方程式の非放射解で あるため, 端面の発光プロファイルとSPP波とを結びつけ るにはさらに詳細な検討が必要である。このため,ここ では, 分解能の限界で議論の必要のない横モードを対象 として定量的検討を進めた。

金属光導波路としての基本特性を明らかにするため, SPP波の伝搬損失測定を行った。测定方法には, 入射光強 度を一定の下に導波路長をパラメータとして出射強度を 測定するカットバック法を採用した。同一試料の長さを かえながら測定するのが困難なため, ここでは種々の長 さの試料を同一ロッドで作製し，長さを変える代わりと した．Fig. 13は測定結果で，導波路幅により多少違いはあ るものの，損失係数は $100 \mathrm{~cm}^{-1}$ 前後と見積もられた。この 值は理論的に予測した值 (Fig. 4 (b))にほほ一致する。こ の結果はSPP波伝搬の傍証となっている.

なお， $40 \mathrm{~cm}^{-1}$ 前後の低損失伝搬を与える結果も得られ ているが，こ机は金属一空気界面を伝搬するSPPに相当す る。ここでは金属誘電体界面のSPPを検討対象としたので このSPPについての詳細検討結果は割愛する。ただし, 分 散関倸から困難であるとされていた金属空気界面SPPの直

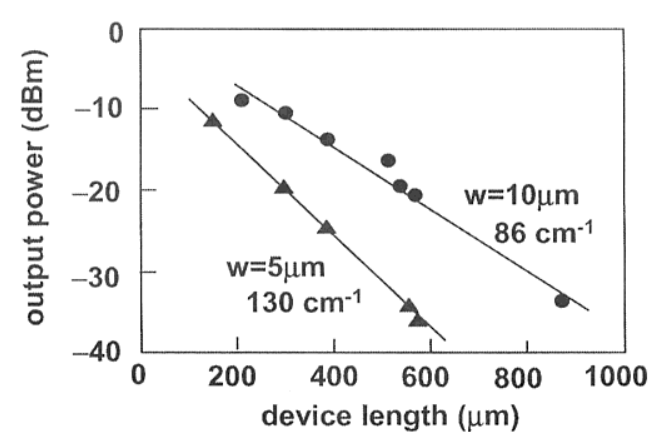

Fig. 13 Estimation of loss coefficient by the cut-back method using output power versus device length relations under the condition of maintaining a constant injection light power.

接励起が端面照射により可能となるということは重要で あり，今後の理論的検討課題である。

\section{2 曲げ導波路におけるSPP波伝搬}

表面プラズモンとフォトンが強く結合しているSPP波伝 播では, 誘電体側の光波を強引に金属との界面に結合さ せているとみなすことができる，従って，金属パターン に屈曲部を設ければ, それに沿ってSPP波も屈曲すること が期待できる。この命題を実験的に検証するため, 極率 半径の小さい屈曲部を有する装荷形導波路を作製し(Fig. 14 (a))，SPP波の伝播特性を調べたＳPP波伝搬を観察し たものをFig. 14 (b)に示す. 入射位置からオフセットされ たところで出力のイルミネーションを観測できたことか ら，SPP波の存在条件を満足する金属パターンに沿って SPP波が屈曲したといえる.

\section{3 ストリップ線路形金属光導波路}

ストリップ線路形金属光導波路は, 金属膜上に誘電体 薄膜を介して金属ストライプを配置した構造を持つ導波 路である(Fig. 15 (a))。前節の実験と同様テテーパーファ イバにより端面を照射してSPP波を励起・伝搬させる。二 つの金属に挟まれた微小な誘電体空間に光をSPP波に変換 して伝搬させることが我々の狙いである。部金属スト ライプー空気界面の伝搬があると我々の目的は達成され

\section{camera}

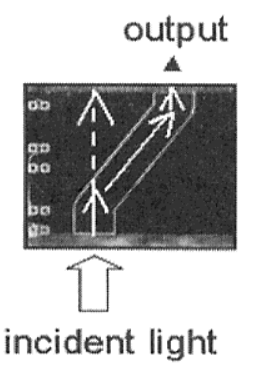

(a)

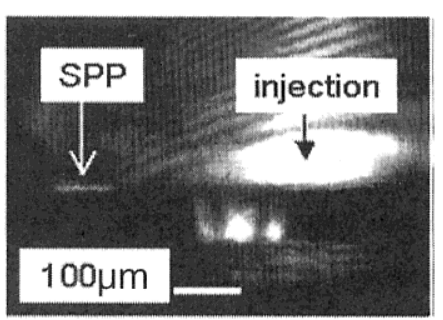

(b)
Fig. 14 SPP propagation along a bent waveguide. (a) Top view of a waveguide device with sharply bent corners and (b) an illumination image to show the evidence that light is bent. 


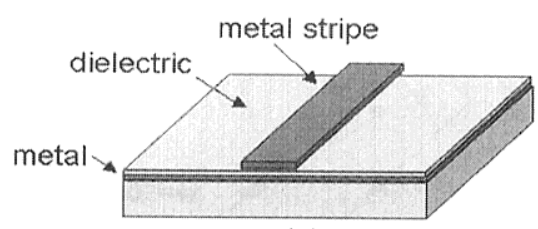

(a)

Au $250 \mathrm{~nm}$

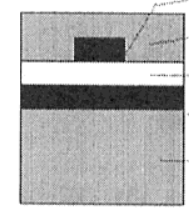

(b)

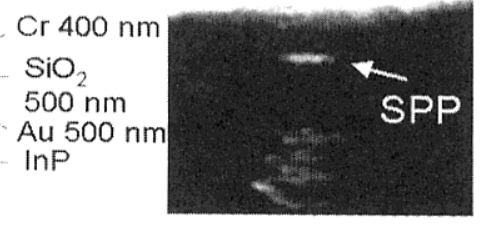

(c)
Fig. 15 SPP propagation along a strip-geometry waveguide. (a) A schematic of a structure consisting of a metal stripe formed on a InP substrate covered with metal and dielectric films. (b) Cross-sectional view used for experiment had an additional $\mathrm{Cr}$ layer at the top of the device, and (c) an illumination image corresponding to the SPP passing through the waveguide.

ない.このような不必要な伝搬の可能性を除去するた め, $1.5 \mu \mathrm{m}$ 帯で誘電率の実数部がほぼ 0 となる $\mathrm{Cr}$ を試料上 部全面に付与した(Fig. 15 (b))。これによりSPP波には二 つの金属の間隙にのみ伝搬することが期待できるように なった. Fig. 15 (c) は1.55 $\mu \mathrm{mTM}$ 波光照射により得られた イルミネーションで, 微小間隙中のSPP波伝搬の傍証と なった。

最小微小間隙は，損失係数による実効的制限を除けば物 理的な制限を受けない。このため，上記実験の間隙500 nm に対応した実効波長の0.48倍よりもはるかに小さい間隙に SPP波を励起・伝搬させることは可能であると考えられ る. 光の存在空間の寸法を波長以下とする場合，3次元的 広がりを持つ自由空間中の光波をそのまま波長以下の間隙 へ導入することは困難なので, 光波を空間凝縮性を有する $\mathrm{SPP}$ 波に変換してこのような微小間隙を伝搬させることは 量子光学的観点からも重要である。このような光の微小間 隙透過は金属膜に規則配列したナノホールの透過実験によ り検証されており, 長距離伝搬は今後の課題である.

\section{5. まとめ}

超微細光回路の実現に向け, 表面プラズモンポラリト ン (SPP) 波に基づく金属光配線技術について解説するとと もに, 我々が進めている実験検証の一部を紹介した。理 論では, 電子系の運動方程式に基づきプラズモンの物理 的描像を明らかにするとともに, Maxwell方程式に基づく SPP波の基礎方程式を導出して分散および損失等伝搬に関 する基本特性が計算により評価できることを示した。さ らにこの手法を拡張し, スラブ形構造を有する金属光導 波路が解析できることを述べた。最も単純な片界面形の 金属光導波路を作製してSPP波伝搬を確認した結果や損失 係数評価によるSPP波伝搬の傍証等, 最近の我々の実験検 証結果を紹介した。さらに，回折限界以下の微小間隙へ の電磁場の閉じ込めを狙いとして我々が進めているナノ
チャネルストリップ線路形導波路におけるSPP波伝搬確認 実験についての最近の結果を紹介した。

現状では誘電体導波路と比較すると，SPP波の伝搬機構 の理論は完全に整備された状態ではない。実用技術とし て成熟するためにはさらなる理論検討が必要である。ま た，理論を検証する実験手段も未熟なところがある。特 にナノメートルのスケールの位置決め制御技術をはじめ とするナノテクノロジーの進展がこの分野の基盤技術確 立には必須となる。しかし，このような課題を克服すれ ば，光信号情報を電子密度波に載せて原子・分子スケー ルにまで及ぶ全く新規の超微細な金属光線路を実現する ことも可能である。また実現した新たな素子を利用する ことにより, 量子電磁力学の基本検証が進展することも 可能である。斬新なアイデアでこの分野が切り開かれて ゆくことに期待する。

\section{参考文献}

1) J. S. Foresi, P. R. Villeneuve, J. Ferrera, E. R. Thosen, G. Steinmeyer, S. Fan, J. D. Joannopoulos, L. C. Kimerling, Henry I. Smith, and E. P. Ippen: Nature 390 (1997) 143.

2) B. E. Little, J. S. Foresi, G. Steinmeyer, E. R. Thoen, S. T. Chu, H. A. Haus, E. P. Ippen, L. C. Kimerling, and W. Greene: IEEE Photon. Technol. Lett. 10 (1998) 549.

3) K. K. Lee, D. R. Lim, H-C. Luan, A. Agarwal, J. Foresi, and L. C. Kimerling: Appl. Phys. Lett. 77 (2000) 1617.

4) A. Sasaki, G. Hara, and T. Baba: Jpn. J. Appl. Phys. 40 (2001) L383.

5) A. Sakai, T. Fukazawa, and T. Baba: IEICE Trans. Electron. E85-C (2002) 1033.

6) T. Shoji, T. Tsuchizawa, T. Watanabe, K. Yamada, and H. Morita: Electron. Lett. 38 (2002) 1669.

7) E. Yablonovitch: Phys. Rev. Lett. 58 (1987) 2059.

8) W. Robertson, G. Arjavalingam, R. Meade, K. Brommer, A. Rappe, and J. Joannopoulos: Phys. Rev. Lett. 68 (1992) 2023.

9) E. Yablonovitch and K. Leung: Physica-B 175 (1991) 81.

10) Shanhui-Fan, P. Villeneuve, and J. Joannopoulos: J. Appl. Phys. 78 (1995) 1415.

11) V. Kuzmiak and A. Maradudin: Phys. Rev. B 57 (1998) 15242.

12）小林哲郎：“光周波数波動伝送線路”, 特願平5-263296.

13) H. Raether: Surface plasmons on smooth and rough surfaces and on gratings, (Springer-Verlag, Berlin Heidelberg 1988).

14) R. H. RItchie: Surf. Sci. 34 (1973) 1.

15) R. Ruppin: Surf. Sci. 34 (1973) 20.

16) E. N. Economou: Phys. Rev. 182 (1969) 539

17) K. L. Ngai: Phys. Rev. 182 (1969) 555.

18) J. J. Burke, G. I. Stegeman, and T. Tamir: Phys. Rev. B 33 (1986) 5186.

19) D. J. Evans, S. Ushioda, and J. D. McMullen: Phys. Rev. Lett. 31 (1973) 369.

20) 高原, 小林：応用物理 68 (1999) 673.

21) J. Takahara, S. Yamagishi, H. Taki, A. Morimoto, and T. Kobayashi: Opt. Lett. 22 (1997) 475.

22) P. Berini: Phys. Rev. B 61 (1999) 10484.

23) B. Lamprecht, J. R. Krenn, G. Schider, H. Ditlbacher, M. Salerno, N. Felidj, A. Leitner, and F. R. Aussenegg: Appl. Phys. Lett. 79 (2001) 51.

24) R. Charbonneau, P. Berini, E. Berolo, and E. Lisicka-Shrek: Opt. Lett. 25 (2000) 844.

25) J. -C. Weeber, J. R. Krenn, A. Dereux, B. Lamprecht, Y. Lacroute, and J. P. Goudonnet: Phys. Rev. B 64 (2001) 045411.

26) 高原, 江田, 小林：応用物理 71 (2002) 685.

27) T. W. Ebbesen, H. J. Lezec, H. F. Ghaemi, T. Thio, and P. A. Wolff: Nature 391 (1998) 667.

28) R. E. Ferguson, F. R. Wallis, and G. Chauvet: Surf. Sci. 82 (1979) 255.

29）固体物理, Vol.16 No.7, 低次元物質, (1981). 